\title{
MIASTO GRUZIŃSKIE - SEMANTYKA WYBRANYCH POJĘĆ
}

\begin{abstract}
Zarys treści Miejscowości zlokalizowane na terenie (obecnej) Gruzji mają przeważnie starożytną i wczesnośredniowieczną genezę. Z tychże okresów pochodzi znaczna część gruzińskojęzycznych terminów opisujących miasto, miejskość i jego mieszkańców. Celem artykułu jest przybliżenie fenomenu miejskości w kontekście semantyki kilku podstawowych pojęć. Znajomość genezy terminu pozwala, zdaniem autorki, dostrzec kulturową pojemność miejsca, do określania których są one używane. W końcowej części tekstu, rozpatrywane wcześniej pojęcia, postrzegane są jako nośniki pamięci historycznej i kulturowej.
\end{abstract}

Słowa kluczowe Semantyka, pamięć kulturowa, gruzińskie miasto, daba, ubani, mkvidri.

\section{Początki miast}

Obszar rozpowszechnienia gruzińskich miast przynależy do przednioazjatyckiego regionu kultur rolniczo-hodowlanych ${ }^{1}$ oraz jest objęty wstęga granicy mrozu, gdzie epoka żelaza rozpoczęła się wcześniej niż na pozostałym obszarze tego regionu (Ballenstedt 2000: 78; McEvedy 1967: 35). Zdaniem wielu badaczy, w regionie kultur rolniczo-hodowlanych typu przednioazjatyckiego, cywilizacja miejska wyprzedzała cywilizację rolniczą (Jacobs 1969: 5-58). Narzędzia pracy wykonane z żelaza przyczyniły się do rozwoju zawodów pozarolniczych (odnajdywanie i wydobywanie zasobu, metalurgia, rzemiosło, systemy irygacyjne), dzięki którym rolnictwo stawało się intensywne i wytwarzało nadprodukcję. Nadmiar produkcji pociągnął za sobą rozwój wymiany i handlu, co stało się bodźcem dla bliskich bądź dalekich podróży (na terenie Gruzji przechodziło północne odgałęzienie starożytnej i średniowiecznej magistrali handlowej).

Z podróżami związany był rozwój dróg oraz doskonalenie kompleksu usług, zapewniających podróżującym nie tylko bezpieczeństwo, lecz również wypoczynek z miejscami do magazynowania przewożonych artykułów oraz noclegu

\footnotetext{
${ }^{1}$ Nazwa „przednioazjatycki” odnosi się do przedniej, tj. zachodniej Azji, http://sjp. pwn.pl/doroszewski/przednioazjatycki;5483199.html.
} 
i pożywienia zarówno dla ludzi, jak i dla siły pociągowej. W starożytnej Gruzji lokalnie używaną nazwą wielofunkcyjnego kompleksu, odpowiednika dzisiejszego zespołu hotelowo-usługowego, było określenie funduki i kulbaki, a w średniowiecznej-karawanseraj) $)^{2}$. W dalszej kolejności rozwijały się bardziej złożone procedury finansowe i prawne związane z płatnościami i obrotem dobrami, które musiały być wymierne względem obszaru włączonego do orbity wymiany i handlu3.

Miasta neolitu, w tym gruzińskie, identyfikowane jako obszary defensywne i bezpieczne, zamieszkałe były przez rolników i nie rolników (Mellaart 1967: 15). W Gruzji najpierw rozwija się jej część wschodnia, zwana Iberią. Była ona zasiedlona wyznawcami lokalnych wierzeń, ale też wyznawcami w Bóstwa Armazi i zoroastryzmu (Lang 1976). Z tego okresu pochodzą najdawniejsze gruzińskie miejscowości opisane w specjalistycznej literaturze przedmiotu jako Armazciche (Tsereteli 1942; Kavtaradze 2009) i Upliscyche (Mepisaszwili, Cincadze 1990: 99-109) oraz stolica starożytnej Gruzji - Mccheta (Apakidze i in. 1958; Apakidze 1968). Archeolodzy uważają, że elipsoidalne wzniesienie w pobliżu Mcchety jest zakonserwowaną pod warstwą ziemi prastolicą plemienną Qarti (Pirveli 2000b: 5-30).

Gruzińskie miejskie cywilizacje prawdopodobnie nie były tak okazałe jak inne śródlądowe cywilizacje rejonu południowo-zachodniej Azji (np. Çatal Hüyük, Eridu, Ur itp.), jednak tutejsza sieć osadnicza była już wystarczająco rozwinięta, by doprowadzić do powstania w połowie I tysiąclecia p.n.e. pierwszego Zjednoczonego Państwa Gruzińskiego (Lortkipanidze 1968; Encyklopedia Gruzińska 1981). Według historyków, już w XII w. p.n.e. budowano na terenie Gruzji bardzo zbliżone do miast siedliska otoczone murem. W rezultacie, z powodu ich przeludnienia w VII w. p.n.e., część mieszkańców wychodziła poza obszar obwarowany, zakładając w pobliżu nowe, nieufortyfikowane siedlisko. Zapoczątkowało to proces zagęszczania sieci osadniczej, zwłaszcza na terenach przyległych warowniom. Był to również początek powstawania bardziej złożonych, wielodzielnicowych i trójukładowych jednostek przestrzennych (najstarsza część z cyche - tj. cytadelą, z nieufortyfikowanymi i przylegającymi od zewnętrznej strony murów warowni, z dzielnicami miejskimi oraz otaczającymi je działkami rolniczymi). Jest to również okres, gdy na obszar gruziński dotarła fala greckiej kolonizacji

${ }^{2}$ Funduki - pojedyncza budowla usługowo-gospodarcza. Kulbaki - kompleks obiektów specjalnego przeznaczenia. Były one przygotowane do podejmowania podróżników lub kupców wraz z całą karawaną. Goście mieli w nich zapewniony nocleg i wyżywienie. Było tam również wydzielone miejsce na drobny handel. Podobne obiekty i kompleksy mieściły się zarówno w mieście, jak i w pewnej od nich odległości. Odległość między podobnymi obiektami nie mogła przekraczać dobowej jazdy. Po okresie starożytnym funduki i kulbaki nazywano karawanserajami

${ }^{3}$ Przy Narodowym Banku Gruzji działa Muzeum Pieniędzy. W gablotach dla odwiedzających wystawione są XXVI-wiekowe monety gruzińskie, które były wybijane w Gruzji (zob. National Bank of Georgia). 
(IX-VI w. p.n.e.). Greckie kolonie zasiedlane były przez małorolnych chłopów oraz ludność bezrolną, która migrowała z Grecji. Kolonie greckie powstawały na wybrzeżach Tracji, w Italii, na Sycylii, w Hiszpanii i Galii, ale też na wschodnich wybrzeżach Morza Czarnego. Z VIII w. p.n.e. pochodzą pierwsze udokumentowane kontakty gospodarcze gruzińskich (iberyjskich i kolchidzkich) miast z greckim Miletem w Azji Mniejszej (Ckitiszwili 1963).

W VII w. p.n.e., wraz z rozpowszechnieniem się pisma alfabetycznego, w świecie greckim wystąpiła wyraźna tendencja do kodyfikacji prawa. R.F. Willetts (1990: 294) uważa, że główny impuls mógł pochodzić z potrzeby zapewnienia kolonistom wywodzącym się z rozmaitych miast, w których obowiązywały różne systemy prawa zwyczajowego, jednego kodeksu prawnego (Dickinson 1961; Carter 1972). Ta znamienna innowacja pojawiła się w pierwszym rzędzie w koloniach greckich położonych na zachodzie, bardziej oddalonych i trudniej dostępnych niźli te, które leżały na wschodzie. Gruzińskie miejskie cywilizacje z tego okresu, według archeologów i historyków, charakteryzowały się wysokim poziomem urbanistycznym. Kolchida - miejsce dokąd Argonauci wyruszyli w poszukiwaniu złotego runa - być może stawiła opór i nie przyjęła greckiego prawa i greckiego układu urbanistycznego autorstwa Hippodamos z Miletu, bądź może greccy rolnicy uznali, że nie jest im potrzebne na tych terenach stworzone przez siebie prawo. Ustalanie tej kwestii nie jest celem autorki. Ważne jest tu jedynie stwierdzenie, że greckie kodyfikowane prawo gospodarcze rozpowszechniło się wyłącznie w zachodniej części obszaru greckiej kolonizacji i spowodowało - zdaniem autorki - pierwszy podział miast wywodzących się z tego samego pnia na wschodnie i zachodnie.

Wschodnie miasta, w tym gruzińskie, nigdy nie poznały kodeksu prawa miejskiego $\mathrm{w}$ rozumieniu praw miejskich zachodnich, tj. wyższości zapisanych ustaleń prawnych ponad podziałami społecznymi i interesami miejskiej elity oraz równości wszystkich mieszczan wobec kodeksu prawa miejskiego. Na terenach miast wschodnich, ponad prawem stał (i stoi) ktoś, kto tworzył (i tworzy) lub egzekwował (i egzekwuje) prawo. Ta zasada, podobnie jak pamięć kulturowa (i historyczna) o Argonautach, jest ciągle żywa w świadomości aktorów społecznych gruzińskiej sceny miejskiej.

\section{Miasto komunikuje się z czlowiekiem}

Miasto komunikuje się z człowiekiem teraźniejszości (z własnej i cudzej przestrzeni kulturowej) poprzez nagromadzone w mieście dziedzictwo materialne i niematerialne oraz opisujące go słownictwo. Zasoby leksykalne oraz nazwy miejsc i obiektów są nośnikiem wielowarstwowej informacji nie tylko o rozwoju języka i genezie nazwy, ale też o zwyczajach, kulturze oraz potrzebach tych ludzi, którzy te nazwy stworzyli. 
W regionach pogranicza, gdzie do głosu dochodzą wpływy sąsiednich, odrębnych kultur, tradycji oraz sposobów budowania i organizowania życiowej (społecznej i gospodarczej) przestrzeni synergizmu kulturowego, semantyka nazw jest bardziej złożona. Zarówno Gruzja, jak i cały Kaukaz jest tyglem kulturowym, regionem konwergencji tradycji, religii i ideologii. Drogę rozwoju miast gruzińskich i miejskości, liczących około 40 wieków historii, wytycza geopolityczne położenie regionu o maksymalnie zróżnicowanej etnicznie strukturze. Ponadto region ten znajduje się na tranzytowej drodze Wschód-Zachód. Tutejsza ludność lokalizowała swoje miasta nad życiodajnymi górskimi rzekami oraz w sejsmicznej strefie na styku kontynentów, ale też styku religii, kultur, szlaków komunikacyjnych czy interesów politycznych bądź gospodarczych dawnych i współczesnych mocarstw świata, przy jednoczesnym istnieniu lokalnie wypracowanych wzorców kulturowych (Pirveli 1999, 2002). Właśnie taki kalejdoskop dziejowy otwiera szeroką gamę pojęć, nazw i terminów związanych z miastem, miejskością i społecznością miejską.

\section{Rejon rolniczy - stosunek do ziemi i pola uprawnego}

Z początkiem gruzińskiej miejskości wiąże się pojawienie bardzo ważnego elementu przestrzenno-strukturalnego - rejonu rolniczego. Rejon rolniczy to życiodajne pola uprawne, otoczone pierścieniem funkcjonalnie zróżnicowanych defensywnych i ofensywnych osiedli. Z czasem wyróżniało się wśród nich miejscowość o strategicznym położeniu, tj. na wzniesieniu (podobnym do greckiego akropolu). Strategiczność takiej lokalizacji polegała na tym, że położona na wzniesieniu osada miała w zasięgu wzroku obszerny rejon rolniczy, dochodzące do niego drogi oraz fragment nieba, jako zwiastuna suszy lub ulewy. Tak usytuowane osiedle było zwykle powiązane z bóstwem i miejscem jego hołdu. Najstarszym opisanym przykładem podobnego strategicznego punktu jest Armazcyche (w pobliżu m. Mccheta, w tłum. twierdza bądź miasto Armazi). Armazcyche to wzgórze powiązane z miejscem kultu najstarszego i najważniejszego pogańskiego synkretycznego Bóstwa Armazi ${ }^{4}$.

Jednocześnie rozpoczął się proces formowania bardziej złożonego mechanizmu transformacji pierwszych stałych siedlisk w gminy miejskie. Polegał on na łączeniu się rozproszonych $\mathrm{w}$ granicach tego samego rejonu rolniczego gmin wiejsko-miejskich. Po ich zespoleniu powstawał jeden, rozproszony i wielofunkcyjny kompleks. Do tak powstałego układu przestrzenno-funkcjonalnego włączały się przede wszystkim te miejscowości, które wykazywały wyraźną specjalizację. Zrzeszając się w złożone struktury przestrzenno-funkcjonalne każda osada

\footnotetext{
${ }^{4}$ Bóg Bogów Bóstwo Armazi - bóg niebios, grzmotów, deszczu i lord roślin. Wyobrażony jest jako stojący na szczycie góry wojownik, odziany w miedziany pancerz, w złotym hełmie i z bagnetem w ręku (Mroveli 1955: 106).
} 
wnosiła do wspólnego organizmu własny obszar łącznie z przyległymi terenami oraz - co ważniejsze - wyspecjalizowane funkcje. Ten typ transformacji określany jest procesem synojkizmu ${ }^{5}$. Mccheta, dawna stolica Gruzji, jest przykładem (nie jedynym) gruzińskiego synojkizmu (Apakidze 1963a: 161, 1963b: 149).

Konkludując ten fragment, należałoby podkreślić, że pole uprawne nie jest w świadomości Gruzinów tylko źródłem wyżywienia czy obszarem rolniczym. W głęboko zakorzenionej historycznej pamięci mieszkańców tego obszaru (i nie tylko w świadomości rolników) pole uprawne jest prapoczątkiem istnienia.

\section{Daba-miejsce wolne i zarazem zależne}

Daba jest nazwą przejściowego typu osiedla między miastem a wsią (Vachuszti 1941: 12). W literaturze ormiańskiej odpowiednikiem gruzińskiego terminu daba jest agaraki i dastakerti (Śremian 1953: 17; Lortkipanidze 1957: 153). W języku gruzińskim również występuje wyraz agaraki, jednak ma on nieco inne znaczenie niż wyraz daba. W dosłownym tłumaczeniu z języka gruzińskiego na polski, agaraki wskazuje na miejscowość wypoczynkową zlokalizowaną w pobliżu miejscowości stałego zamieszkania człowieka, w której zwykle ta osoba spędza wakacje. Mianem agaraki można też nazwać własny drugi dom o funkcjach wypoczynkowych. Natomiast daba jest nomenklaturą podziału administracyjnego; pozycjonuje miejscowość jako formę pośrednią między miastem a wsią. W Gruzji obecnie istnieje ponad 50 daba.

W Gruzji daba pojawiły się w już starożytności. Były to osady zlokalizowane w bliskiej odległości od miast. Nie miały własnych fortyfikacji i pod tym względem były całkowicie zależne od miasta. Nie miały też własnych pól rolniczych, co uzależniało je od wiosek. Niekiedy, gdy były położone bezpośrednio przy bramach miejskich, nazywano je przedmieściami ${ }^{6}$.

Daba jest bardzo charakterystycznym i zawsze współistniejącym z miastem elementem przestrzennym. Rozwijająca się na terenie daba aktywność kupiecka nie podlegała ocleniu, tak jak przywóz towarów, za które cło było pobierane po przekroczeniu bram miejskich czy mostu. W okresie Złotego Wieku przyszło im pełnić bardzo ważną misję. Otóż daba jako jedyna forma osiedli, nie była czyjąś

${ }^{5}$ Synojkizm (od greckiego synoikismos - współżycie) - termin określający (w archaicznej Grecji) proces tworzenia polis poprzez łączenie się niezależnych gmin wokół jednego ośrodka centralnego.

${ }^{6} \mathrm{~W}$ gruzińskiej rzeczywistości termin przedmieście pojawia się w dwojakim znaczeniu: 1) daba jako kategoria podziału administracyjnego, która jest zlokalizowana w bezpośrednim sąsiedztwie bram miejskich, 2) skupisko ludzi, które z powodu zagęszczenia liczby mieszkańców w mieście, wychodzi poza fortyfikację miejską i gospodaruje na terenach przyległych. Pierwsza forma jest wyrazem powstawania miast w procesie synojkizmu. Druga forma jest wyrazem wzrostu liczby mieszkańców w mieście. 
własnością. Kupcy chcieli ukonstytuować ją jako wolne miasto. Nigdy jednak w Gruzji nie doszło do powstania wolnych miast (zawsze były one własnością feudałów) prawdopodobnie dlatego, że w czasach dobrobytu w państwie, królewska (feudalna) władza była zbyt silna, a kultura dialogu (obywatelskiego) - była nazbyt słaba. Te daba, które były najniebezpieczniejsze, tj. gdzie lokalna społeczność posiadła zbyt dużą władzę, włączano je w granice miast stołecznych księstw (regionów) i całej Gruzji.

Vere, dzisiejsza śródmiejska dzielnica Tbilisi, do połowy XIX wieku stanowiła daba Vere. Jednym ze współczesnych przykładów daba jest nad Tbilisi górujące Tckneti oraz pierścień innych daba wokół Tbilisi: Cavkisi, Kiketi, Kojori, Tabachmela, Betania, Lilo, Oqrokana, Achaldaba. W literaturze anglojęzycznej Tckneti jest określane jako urban village. W czasach obecnych zauważalny jest odpływ lepiej usytuowanych rodzin z Tbilisi do pobliskich daba, które tradycyjnie były bardziej wolne aniżeli skomercjalizowana przestrzeń Tbilisi. Od niedawna, (o dziwo!), okoliczne daba zostały włączone w granice administracyjne Tbilisi. Tym posunięciem miejscowości te zostały objęte administracją Tbilisi.

\section{Wielodzielnicowość i mozaika społeczna - cecha organiczna}

Wielodzielnicowość i mozaika społeczna to właściwości wpisane w pradzieje powstawania gruzińskich miast. Podstawę do wyróżniania miejskiej dzielnicy stanowiła specjalizacja skupionej grupy rzemieślników oraz cechy topograficzne zagospodarowanego (oswojonego) przez nich terenu. Niekiedy w toponimice dzielnicy były i są zaznaczone cechy: topograficzne (wąwóz - dzielnica wąwozowa, dolina - dzielnica dolinna, skała - dzielnica skalna, dzielnica przedmieścia), przyrodnicze terenu (dzielnica róż, lip), wykonywanego zawodu (dzielnica garncarzy, złotników, szklarzy, tkaczy, kowali i wytwórców wyrobów metalowych). Dzielnice wytwórców wyrobów metalowych nazywano również dzielnicą „żelaznych ludzi” (żelazo - poladi). Prawdopodobnie właśnie z tymi pradawnymi zawodami wiąże się geneza niektórych gruzińskich imion i nazwisk (Poladauri) - jednak nie jest to tematem niniejszego tekstu.

Społeczność zamieszkująca gruzińskie miasta była i jest złożona i rozwarstwiona pod względem materialnym, zawodowym, etnicznym i religijnym (Dźawachiszwili 1960). Historycy uważają, że jest to wynik ich położenia na szlaku handlowym oraz faktu, że Kaukaz stanowi ojczyznę ponad 100 różnych grup etnicznych (Cilaszwili 1964). W starożytności, poza językiem gruzińskim, ogólnie używanym przez mieszczan był język grecki, ormiański, chazarski (dialekt północnoirański), asyryjski (syryjsko-aramejski) i hebrajski. Poszczególne grupy etniczne tworzyły własne dzielnice (Meschia 1951). Nie istniała tylko dzielnica gruzińska, bowiem Gruzini rozproszeni byli po całym mieście i stanowili w nim najczęściej większość; najwięcej jednak było ich w centralnej dzielnicy. Zarówno szlachta, jak i arystokracja były gruzińskie. 
Dzielnicę wyróżniano również na podstawie wiary. Wyznawcy różnych religii, co nie jest jednoznaczne z grupą etniczną, składali hołd swoim bóstwom, budując obiekt sakralny lub wyznaczając w swojej dzielnicy miejsce święte. Najczęściej miejsce sakralne danej grupy wyznaniowej kreował odrębny charakter dzielnicy. W scenerii dzisiejszej Tbilisi ta cecha nadal jest widoczna poprzez koncentrację w historycznej części miasta obiektów sakralnych różnych wyznań. Jedna z najstarszych pogańskich świątyń tbiliskiej społeczności - Ateshgah (ICOMOS 2008: 47), znajduje się w tej części dzielnicy Betlemi, które nazywa się kldisubani (skalne ubani).

W socjotopografii występowała i częściowo nadał występuje współzależność między grupą etniczną a wykonywanym zawodem, np. żydowska grupa etniczna w miastach gruzińskich związana była najczęściej z handlem i tworzyła swoje dzielnice przeważnie w pobliżu miejsc targowych (Dźawachiszwili 1965). Mozaika etniczna i religijna dla Gruzji i jej miast jest cechą genetyczną liczącą tyle wieków, ile liczy sama Gruzja. Na przełomie XVIII-XIX stulecia wyłącznie w Tbilisi pojawiła się grupa etnograficzna (IE etniczna!) - etnos Kinto. Byli oni organiczną częścią wielonarodowego miasta i nadawali Tbilisi niepowtarzalny koloryt. Charakterologicznie Kinto reprezentowali mieszankę cech narodowych Azerbejdżanina, Ormianina i Gruzina (od jednych wzięli mądrość, od drugich zdolność do handlu, a od trzecich ,język jak miód"). Stworzyli własny stereotyp z własnym stylem ubioru, sposobem mówienia, zachowania, własną muzykę i poezję. Kinto trudnili się drobnym handlem i rzemiosłem oraz byli znakomitymi wodzirejami imprez. Mimo to, że grupa ta - podobnie jak wiele innych osobliwości Tbilisi i Gruzji - zniknęła wraz z nadejściem reżimu sowieckiego, to jednak pozostawiła trwały ślad w folklorze (Pirveli 2000a: 10-11).

Poza wspomnianymi wyżej kryteriami, do wyodrębnienia dzielnicy służyły niektóre obiekty zabudowy miejskiej, jak np. abano (łażnia) ${ }^{7}$, saasparezo (stadion) $)^{8}$, sagodebeli (cmentarz) $)^{9}$ czy cyche (twierdza), bądź główny obiekt

${ }^{7}$ Abano - tj. łaźnie lub termy (ale nie sauna). Są one nieodłącznym elementem zabudowy miejskiej. Archeolodzy w każdym mieście potwierdzają występowanie łaźni; częste są przypadki, gdy jedno miasto posiadało kilka term. Termy dysponowały dość skomplikowanym systemem ogrzewania zarówno wody, jak i pomieszczeń. Mozaikowo wykonane podłogi i ściany oraz hipokaustyczny system ogrzewania świadczą nie tylko o wysokiej kulturze inżynieryjno-budowlanej, roli sztuki w tego typu obiektach o specjalnym przeznaczeniu, lecz również liczba abano w jednej miejscowości świadczy o randze miasta.

${ }^{8}$ Saasparezo (tj. stadion) - nazwa w dosłownym tłumaczeniu oznacza miejsce rywalizacji bądź miejsce pokazów wymagających dużej przestrzeni. Odbywały się tam igrzyska sportowe oraz inne uroczystości z udziałem dużej liczby osób. Stadion był w każdym mieście, jednak jego wielkość zależała od liczby mieszkańców i rangi miasta. Na przykład w Mcchecie stadion zajmował obszar równy dzielnicy.

${ }_{9}^{9}$ Sagodebeli (obecnie sasaplao - tj. cmentarz). Gruziński wyraz godeba jest płaczem żałobnym z powodu utraty kogoś lub czegoś bardzo cennego. Sagodobelei jest nazwą miejsca, gdzie ludzie w konkretny sposób wyrażają swój smutek. W niektórych regionach Gruzji powstał nawet cały folklor płaczu żałobnego. W mieście i na wsi jest to nazwą 
sakralny Gruzinów. Z wymienionych obiektów najlepiej zachował się w toponimice wyraz - abano (np. abano-t-ubani - nazwa tbiliskiej staromiejskiej dzielnicy).

\section{Cyche (twierdza) lub cytadela - ostoja wladzy}

Cyche (pol. twierdza) jest gruzińskim odpowiednikiem orientalnej cytadeli i greckiego akropolu. W literaturze przedmiotu znane jest cyche wolnostojące (cyklopy) oraz cyche, które ogniskowały powstawanie najpierw defensywnych, a potem ofensywnych zaczątków osad miejskich, zaś cyche (w starożytności) jest synonimem terminu miasto (Pirveli 2002: 16-17; 2009). Istnieje wiele miast (np. Axalcyche - tj. nowe miasto, Upliscyche - tj. miasto Boga), których nazwy zawierają rdzeń cyche, podobnie jak przy dodawaniu polis (Archeopolis, Neapolis).

Twierdza i cytadela były używane do określania najstarszej dzielnicy miasta z głównym placem - centrum miasta. Górujące nad Tbilisi ruiny Narikala (mała twierdza) jest przykładem podobnej dzielnicy. W centralnych dzielnicach mieszkała arystokracja, duchowieństwo, elita wojskowa oraz ich służba. Na początku naszej ery pojawiła się społeczna różnica między dużym a małym miastem. W dużych miastach, arystokracja wywodząca się z królewskiej rodziny, przeniosła się z głównej dzielnicy do rezydencji na peryferie lub poza obwarowane obszary miejskie. W małych miastach twierdza nadal pozostawała zarówno siedzibą, jak i rezydencją właścicieli miasta (właścicielem był duży lub mały feudał; największym feudałem był król).

Termin $t$ wierdza, w znaczeniu metaforycznym, używa się również w odniesieniu do wybranego fragmentu miasta bez obiektu twierdzy i wskazuje na uprzywilejowanie miejsca. Przyczyną nazywania wybranego fragmentu miasta twierdzą może być motyw polityczny, administracyjny czy religijny pozwalający na centralizację władzy polityczno-administracyjnej lub religijno-administracyjnej. W podobnym kontekście (metaforycznie) nazwany twierdzą fragment miasta (nie dzielnica) zawiera w swoich granicach dominantę przestrzenną, która jest zarówno punktem orientacyjnym, jak i wyznaczającym centrum najbliższego otoczenia. Ta cecha nie wywodzi się ze starożytności, lecz ze wczesnego średniowiecza, tj. z początku Imperium Bizantyjskiego.

miejsca chowania zmarłych - cmentarza. Przed okresem radzieckim i poczynając od starożytności, każde miasto posiadało co najmniej dwa cmentarze: jeden dla arystokracji, drugi dla pozostałych mieszkańców. Wyznawcy innej wiary mieli swoje osobne miejsca dla zmarłych. Na przykład w dzielnicy żydowskiej prawie zawsze znajdował się cmentarz. W miastach stołecznych i w niektórych wioskach były katakumby. Chowano w nich członków rodzin królewskich i zamożnych ziemian, tj. wysokiej arystokracji. Cmentarz zwykle mieścił się poza obszarem zabudowanym, ale nie na terenach rolniczych. O odległości między miastem a cmentarzem decydowały warunki topograficzne z uwzględnieniem nachylenia terenu. 
Metaforycznie określoną twierdzą może być ostoja władzy świeckiej (np. rezydencja prezydenta w Tbilisi), kościelnej (np. Katedra Sameba w Tbilisi), gospodarczej (?), społecznej (?) czy jeszcze innej. Znaki zapytania wpisane w nawiasach, zamiast podawania przykładów wyznaczających gospodarcze i społeczne centrum, są zamierzone. Brak jest we współczesnej przestrzeni Tbilisi metaforycznej twierdzy gospodarczej i społecznej władzy, które mogłyby stanowić przeciwwagę względem twierdzy władzy świeckiej i kościelnej (chociażby w celu wspólnego zarządzania miastem). Prawdopodobnie zrodzą się one z obecnych pozarządowych organizacji (NGO) i lokalnych małych i średnich przedsiębiorstw (MŚP). Z drugiej strony, odpowiedniej mocy potencjał społeczny, który pozwoli stworzyć wystarczająco silne i niepowiązane z władzą NGO i MŚP, drzemie właśnie w tych grupach społecznych, które opuściły Tbilisi i przeniosły się do okolicznych daba przed 2006 rokiem. „Ucieczka” z Tbilisi okazała się nieudana, ponieważ daba od 2006 roku zostały włączone do granic administracyjnych Tbilisi.

W ostatnich latach zniszczono (osłabione w okresie radzieckim) historycznie wytworzone centra społeczne (ubani) i gospodarcze (bazar), a nowych na ich miejscu lokalna społeczność jeszcze nie wytworzyła. Jednocześnie faktem jest, że w publicznej przestrzeni gruzińskich miast są i zawsze były liczne miejsca spotkań i handlu. Niemniej, znaczenie takich miejsc (chyba) nie stanowi przeciwwagi dla władzy świeckiej i kościelnej. Są one obecnie jedynie „łatwym celem” dla politycznych ugrupowań chcących zaznaczyć swoją obecność oraz przewagę nad innym ugrupowaniem poprzez ,poparcie społeczne”, wyrażone w niepokojach społecznych i w sprowokowanej ulicznej walce. Inaczej mówiąc, to wykreowane z mocy społecznej potężne narzędzie lobbingu politycznego.

W rezultacie, gruzińskie miasta XXI wieku, podobnie jak inne miasta wschodu oraz post-sowieckie, nadal trwają w początkowej fazie transformacji ustrojowej, nadal nie znają zasad funkcjonowania $w$ warunkach praw miejskich i obce im są miasta wolne czy samorządowe. Brak występowania „twierdzy” społecznego centrum w rozumowaniu ostoi opinii publicznej ma, w pewnym sensie, starożytną genezę. W gruzińskich miastach nigdy nie powstała agora $\mathrm{w}$ rozumieniu greckiej agory, która była wyrazem kultury obywatelskiej oraz cechą czy ostoją greckiej demokracji.

\section{Ubani i ubieli - przejaw wspólnotowości}

Nazwa ubani wywodzi się ze starej formy czasownika „mówić” lub „rozmawiać”. Ubani można wyobrazić jako (sub)centra (Meschia 1950; Melikiszwili 1955), gdzie ludzie spotykali się i rozmawiali. Każda dzielnica miała jedno lub więcej ubani (jakby osiedle mieszkaniowe z własnym centrum). Myśląc kategoriami greckiej agory, gruzińskie ubani pod względem społecznej i gospodarczej funkcji jest jej odpowiednikiem. Zasadnicza jednak różnica między agora a ubani polega 
na tym, że ubani była pozbawiona politycznej wagi wypowiedzianych tam opinii, a wśród osób wypowiadających swoją opinię nie wykształciła się kultura obywatelska i kultura prowadzenia dialogu obywatelskiego, co w przypadku agory było osnową samorządności lokalnej oraz wolności miast i jego mieszkańców. W gruzińskich miastach i jego społecznościach brak tego podobieństwa widoczny jest aż do czasów obecnych. W realiach XXI wieku następuje przysłowiowe „nadrabianie" utraconej w starożytności możliwości, poprzez branie (metaforycznych) lekcji zachowania obywatelskiego.

\section{Ubani jako styl życia i wspólnota interesów}

Ruchliwe i gwarne życie wielonarodowych i wąskich ulic podtrzymywane było typową dla miast zabudową mieszkaniową. Podwórza i balkony (lub szuszabandi ${ }^{10}$ ) od strony ulicy, sprzyjały ścisłym kontaktom ich mieszkańców zarówno między sobą, jak i ze światem zewnętrznym. Większość budynków miała wewnętrzny dziedziniec, z którym połączone były poszczególne pomieszczenia. Dziedziniec wychodził poprzez bramę na ulicę. Dzięki warunkom klimatycznym oraz rządzącym tu zasadom społecznym, mieszkańcy miasta mogli bez ograniczeń przebywać na otwartej przestrzeni (Gabaszwili 1971). Następowało coś, co można nazwać przeplataniem ulicznej i podwórkowej „doby” przechodniów i mieszkańców. Sprzyjało to i warunkowało pogłębienie relacji społecznych i zażyłości między mieszkańcami ubani. Tą zażyłość uwarunkowaną i wynikającą z układów ulic i cech zabudowy oraz ze stylu życia mieszkańców ubani, rozpatrywać można w kontekście: a) zasiedziałości mieszkańców tychże subcentrów (ubani), b) ich wspólnych cech społeczno-kulturowo-zawodowych (co wynikało ze specjalizacji i cech religijno-etnicznych dzielnic). Te cechy to najważniejsze komponenty budujące i strukturalizujące styl życia i wspólnotę interesów gospodarzy ubani.

Rozróżnienie rangi ulic i placów według nawierzchni oraz funkcjonalny podział miejskiej przestrzeni według koncentracji zawodów i podmiotów gospodarczych jest cechą charakterystyczną nie tylko miast gruzińskich. Jest to podstawa do mówienia o socjotopografii. Socjotopografia i hierarchizacja przestrzeni wewnątrz subcentrów, z których składało się miasto, wyrażona była w cechach fizjonomicznych zabudowy, nawierzchni ulic i placów, w ubiorze, gestach i gwarze ulicznej. Odległość od głównego centrum, przy jednoczesnym istnieniu lokalnego (sub)centrum (ubani), czynnik gospodarczy i społeczny oraz zawody wykonywane przez mieszkańców poszczególnych ubani (osiedli mieszkaniowych) strukturalizowały całe miasto. Sama nazwa ubani jest kategorią przestrzenną. Niemniej jednak, mówiąc o ubani ma się na myśli bardzo konkretne i społecznie skonsolidowane grupy społeczne, które z przestrzenią fizykalną mają tyle wspól-

\footnotetext{
${ }^{10}$ Szuszabandi - w dosłownym thumaczeniu oznacza oszklony balkon.
} 
nego, na ile tworząca ubani grupa społeczna działa i koncentruje swoją aktywność w przestrzeni fizykalnej. W języku gruzińskim występuje termin ubneli (kategoria społeczna). Ubneli wskazuje na pochodzenie osoby z tego samego ubani.

W języku polskim, do gruzińskiego wyrazu ubneli, najlepiej pasuje wyraz ziomek, rodak, krajan, z tym że pochodzenie kogoś, kogo określa się mianem ubneli jest zawężone do bardzo konkretnego ubani. Nazywanie kogoś mianem ubneli nie odnosi się do narodowości, religii bądź prowincji historycznej, lecz oznacza zwyczaje i styl życia, które cechują mieszkańców danego ubani.

W scenerii gruzińskich miast znaczenie ubani i ubneli przetrwało czasy radzieckie i pojawienie się w mieście nowych jednostek urbanistycznych - osiedli mieszkaniowych czy nawet blokowisk. Wielokrotnie rozproszeni w nowych osiedlach mieszkaniowych mieszkańcy (ubneli) dawnych ubani, nadal utrzymywali ze sobą dobrosąsiedzkie relacje mieszkając $\mathrm{w}$ oddalonych od siebie częściach miasta. Z biegiem czasu mieszkańcy korpusów mieszkaniowych nawiązywali wzorowane na ubani relacje, jednak okazały się one mniej trwałe i mniej zażyłe aniżeli w ubani. Prawdopodobnie przyczyną tego była mniej uspołeczniona przestrzeń publiczna korpusów oraz - co ważniejsze - przemieszanie struktur społecznych i w rezultacie kumulowanie w granicach jednego kwartału mieszkaniowego ludzi o zdecydowanie odmiennym stylu życia i zainteresowaniach. W ten sposób utracono wypracowane przez wieki odczucie swojskości ubani i ubneli. Niemniej przetrwała pojemność semantyczna tych pojęć, które już nie odnoszą się tylko do skoncentrowanych w przestrzeni fizykalnej grup społecznych, lecz do rozproszonych poza obszar dawnych ubani osób, niegdyś będącymi ubneli. Na terenie ubani pozostało natomiast jedynie materialne dziedzictwo wytworzone przez ich dawnych mieszkańców, których spadkobiercy są rozrzuceni w różnych częściach świata. Dziedzictwo kulturowe dawnego ubani jest dziś zagospodarowane i użytkowane przez osoby słabo rozumiejące i odczuwające swojskość zastanego materialnego dziedzictwa. W rezultacie materialne dziedzictwo i oznaka swojskości ubani, będące w złym stanie technicznym, jest nieraz postrzegane jako nikczemna ruina.

W ciągu ostatnich kilku lat, bogata w dziedzictwo kulturowe przestrzeń publiczna miast gruzińskich, modeluje ukrywający się za hasłem ,atrakcyjności turystycznej” i ,rewitalizacji” czynnik polityczny. Następuje pozorne (kosmetyczne) odnowienie fasady i infrastruktury w celu uwypuklenia cech urbanistycznego dziedzictwa ubani. Jednak ubani utraciło swoją najważniejszą cechę - swoistość i spójność społeczną, co wielokrotnie staje się przyczyną fasadowości prowadzonych prac. W rezultacie pojawia się kicz społeczny, kicz przestrzenny i kicz urbanistyczny, przy czym kicz urbanistyczny nie zawsze jest wynikiem bezgustowności pojedynczych obiektów. Raczej jest efektem lokalizowania w historycznej przestrzeni miasta obiektów i elementów architektonicznych niezwiązanych z kulturową przestrzenią ubani. Przestrzeń dzisiejszego gruzińskiego miasta 
modeluje inna niż tradycyjna zasada; w przyszłości może się okazać, że jest to zasada „dobra” bądź „zła”, jednak już teraz wiadomo, że jest ona oderwana od tradycyjnego społecznego i gospodarczego kryterium modelującego przestrzeń ubani (niegdyś wyjątkowych fragmentów gruzińskiego miasta).

\section{Mkvidri - społeczne spoiwo miejskości}

Podział miejskiej przestrzeni na ubani i miejskiej społeczności na ubneli tylko pozornie różnicowało miasto. W rzeczywistości miasto pozostawało spójnym organizmem, poprzez utożsamianie się mieszkańców ze „swoim” miastem czy rejonem miejskim, którego byli obywatelami. W literaturze gruzińskiej dla określenia mieszkańca miasta występuje specjalny termin mkvidri. W dosłownym tłumaczeniu mkvidri oznacza „miejscowy” poprzez zasiedziałość. Termin mkvidri odnosi się tylko do mieszkańców miasta (a nie całego państwa) i jest gruzińskim odpowiednikiem civitas. Miasto było czymś więcej niż tylko sumą jego poszczególnych części (ubani), dodatkowo posiadało specyficzną ,aurę” miejskości. Ta aura czy atmosfera wytwarzała się właśnie dzięki różnorodności i zarazem poczuciu więzi z miastem jako miejscem. Różnorodność nadawała (i nadaje) miastom gruzińskim niepowtarzalny charakter i sprawiała, że były one niepodobne do innych miast Kaukazu. Ta inność wynikała prawdopodobnie z faktu, że zarówno ubneli, jak i mkvidri reprezentowali odmienne religie, narodowość i zawody. Charakterystyczną cechą gruzińskich miast jest jedność w różnorodności.

\section{Pojęcie - trwały nośnik pamięci kulturowej}

Znaczenie nazwy odkrywa kontekst formowania fizykalnej, społecznej i kulturowej przestrzeni miast, która jest wyrażona $\mathrm{w}$ formach leksykalnych. Znaczenie pojęć związanych z gruzińskim miastem i miejskością jest swego rodzaju pomostem, spoiwem i syntezą dawnych i obecnych dziejów. Ich znaczeniowa pojemność wypełnia egzystencjalną przestrzeń właściwą dla nich atmosferą. Nazewnictwo i terminologia to również swego rodzaju kulturowy konsensus między jednym a drugim człowiekiem w przeszłości i teraźniejszości oraz między historią a zróżnicowaną - językowo, etnicznie, religijnie i światopoglądowo - lokalną społecznością i zakładanymi przez nich instytucjami (Pirveli 2008).

Florian Znaniecki pisał, że człowiek - istota myśląca - jest integralną częścią szerszej historii kultury, której jest twórcą. Pamięć historyczna dotyczy wydarzeń przeszłości. Stanowi istotny składnik tożsamości i samoidentyfikacji każdego człowieka. „Pamięć jest tą zasadą, która prowadzi nieustanną walkę ze śmiercionośną zasadą czasu. Pamięć jest walką ze śmiercionośną władzą czasu w imię wieczności (...). Pamięć historyczna jest największym przejawem ducha wieczności w naszej rzeczywistości czasowej (...). Przez pamięć odtwarzamy minioną 
przeszłość, umarłą, oddaloną od nas, jak się wydaje, odeszłą w jakąś ciemną otchłań" (Bierdiajew 2002: 53).

Jan Assmann stworzył pojęcie pamięci kultury. Pamięć kultury odnosi się do pewnych stałych form - pojęć, tekstów, rytuałów, postaw, obrazów itd. J. Assmann nazywa je „figurami pamięci” lub „wyspami czasu” wyłaniającymi się ,z płynącej rzeki codziennych komunikatów” (Assmann 1988: 12). Za sprawą „figur pamięci”, pamięć kultury przezwycięża czas. Według J. Assmanna pamięć kulturowa (historyczna) jest czymś odrębnym od wiedzy historycznej (Cichocki 2010). Jest ona w pewnym stopniu pamięcią zastygłą. Czas, o którym mówi nie posiada już świadków, zachowany jest jedynie w wytworach kultury (tu: w języku), nie może być niczyim wspomnieniem. Pamięć kulturowa to pamięć o czasie zaprzeszłym, znanym jedynie z przekazu kulturowego. Pamięć kulturowa to pamięć o czasie poza horyzontem żyjących pokoleń. „Jej sednem jest zinstytucjonalizowana mnemotechnika. Pamięć kulturowa orientuje się według stałych punktów w przeszłości (...), przeszłość zastyga tu w postaci figur symbolicznych, do których przywiera pamięć (...). Pamięć kulturowa rejestruje nie faktyczną, ale wspominaną historię (Assmann 1999: 52).

Pamięć kulturowa o gruzińskiej miejskości dostępna poprzez językowe wytwory kultury przemawia o czasach zaprzeszłych i nawiązuje do współczesności. Pojęcia opisane w tekście to - z jednej strony - „wyspy czasu” i ,figury pamięci”, z drugiej zaś - teraźniejszość. Ich semantyka i wielowarstwowa społeczna pojemność opisuje nie tylko przestrzeń egzystencjalną ludzi zamieszkujących tereny dzisiejszej Gruzji. Pojęcia te nadal są w użyciu, nadal stanowią leksykalne zasoby dzisiejszego języka, chociaż ich geneza sięga do starożytności. Za ich sprawą kulturowa tożsamość tamtejszych mieszkańców oraz czas stał się nierozerwalną całością. Jak wszystko na świecie, również ta ciągłość kulturowa ma swój słaby punkt. Zdaniem autorki słabym punktem może być błędne zastosowanie mnemotechniki ${ }^{11}$. Błędnemu zapamiętaniu i przechowywaniu błędnej informacji może przysłużyć jedna z głównych cech pamięci kulturowej (historycznej). Mianowicie to, że jest ona (pamięć kulturowa) od wiedzy historycznej czymś odrębnym (Cichocki 2010). Zatem ktoś (niezależnie od pochodzenia), kto nie zna zamierzchłej, jednak udokumentowanej historii dziejów Gruzji, może tendencyjnie wypełnić te prastare pojęcia inną treścią.

\section{LITERATURA}

Apakidze A.M. i in., 1958, Mtskheta, itogi arkheologicheskikh issledovaniü, t. 1, Tbilisi. Apakidze A., 1963a, Miasta i miejskie życie w dawnej Gruzji, t. 1, Tbilisi.

Apakidze A., 1963b, Rezultaty archeologiczeskogo izuczenia antycznych gorodow Gruzji, Moskwa.

${ }^{11}$ Mnemotechnika pochodzi od mnemonika (gr. mneme - pamięć). Jest ogólną nazwą technik ułatwiających zapamiętanie, przechowywanie i przypominanie sobie informacji. 
Apakidze A.M., 1968, Miasta drewniej Gruzji, Tbilisi.

Assmann J., 1988, Kollektives Gedächtnis und kulturelle Identität, [w:] Assmann J., Hölscher T. (red.), Kultur und Gedächtnis, Suhrkamp, Frankfurt/M.

Assmann J., 1999, Das kulturelle Gedächtnis. Schrift, Erinnerung und politische Identität in frühen Hochkulturen, München.

Ballenstedt J., 2000, Architektura - historia i teoria, PWN, Warszawa-Poznań.

Bierdiajew M., 2002, Sens historii, tłum. Henryk Paprocki, Wydawnictwo ANTYK, Kęty.

Carter H., 1972, An Introduction to Urban Historical Geography, t. 1, część 1 i 2, London.

Cichocki M., 2010, Czas i polityka, Portal: Ośrodek Myśli Politycznej, http://www.omp. org.pl/artykul.php?artykul=142 (dostęp: 10.02.2013).

Cilaszwili L., 1964, Urbnisi, Tbilisi.

Ckitiszwili O., 1963, Pojawienie się średniowiecznego miasta na terenie Środkowego Wschodu, Tbilisi.

Dickinson R.E., 1961, The West European City, London.

Dźawachiszwili I., 1960, Historia narodu gruzińskiego, t. 1, Tbilisi.

Dźawachiszwili I., 1965, Materiały dla istorii materialnoj kultury gruzińskogo naroda, t. II, Tbilisi.

Encyklopedia Gruzińska, 1981, Tom dla rosyjskojęzycznych czytelników, Tbilisi.

Gabaszwili K., 1971, Historia miast gruzińskich, Tbilisi.

ICOMOS, 2008, Annual Report 2008, vol. 1, www.international.icomos.org/annual_reports/2008/pdf/A-REPORT_2008_volume-1_final.pdf (dostęp: 10.02.2013).

Jacobs J., 1969, The Economy of Cities, London.

Kavtaradze G.L., 2009, To the Essence of Deities of Pagan Iberia, „Caucasian and Near Eastern Studies", 13, Giorgi Melikishvili Memorial Volume, Ivane Javakhishvili Institute of History and Ethnology, Tbilisi.

Lang D.M., 1976, Lives and Legends of the Georgian Saints, $2^{\text {nd }}$ ed., London-New York. Lortkipanidze O.D., 1957, Rzemiosło $i$ handel w Mcchecie w stuleciach I-III p.n.e., „Prace Naukowe Tbiliskiego Uniwersytetu", 65, Tbilisi.

Lortkipanidze O.D., 1968, Antikuri samqaro da Kartlis samepo, Iberia (The Classical World and the Kingdom of Kartli or Iberia), Tbilisi.

McEvedy, 1967, The Penguin Atlas of Ansient History, Sheck Wah Tong Printing Press Ltd., Hong Kong.

Melikiszwili G., 1955, Petryfikacja społeczna i pojawienie się państwowości w Gruzji, Tbilisi.

Mellaart J., 1967, Çatal hüyük: A Neolithic Town in Anatolia, Londyn.

Mepisaszwili A., Cincadze A., 1990, Leksykon historyczny Gruzji.

Meschia Sz., 1950, 1959, Miasta i ustrój miejski w Gruzji, Tbilisi.

Meschia Sz., 1951, Na temat procesów społecznych w gruzińskich miastach, Tbilisi.

Mroveli L., 1955, Dzieje Kartli, t. 1, Tbilisi.

Narodowy Komitet Ochrony Dziedzictwa Kulturowego, http://heritagesites.ge/?lang=eng \&page $=240$ (dostęp: 10.02.2013).

National Bank of Georgia - Georgian Money - Money Museum, http:/www.nbg.gov.ge/ index.php?m=405\&lng=eng (dostęp: 10.02.2013).

Pirveli M., 1999, Poczatki osadnictwa Gruzji, „Acta Universitatis Lodziensis. Folia Geographica", 2, s. 97-108. 
Pirveli M., 2000a, Podstawy teoretyczne urbanistyki socrealizmu, XIII Konwersatorium Wiedzy o Mieście, s. 17-25.

Pirveli M., 2000b, Potencjalne walory turystyczne Gruzji, „Turyzm”, 10(2), s. 5-30.

Pirveli M., 2002, Miasto gruzińskie w świetle europejskiej i orientalnej koncepcji urbanistycznej, Dialog, Warszawa.

Pirveli M., 2008, Miasto - przestrzeń semantyczna, Zapol, Szczecin.

Pirveli M., 2008, Tbilisi-etapyurbanistycznegorozwojumiasta, Studia RegionalneiLokalne, Centrum Europejskich Studiów Regionalnych i Lokalnych UW, Sekcja Polska Regional Studies Association, 4, s. 24-39.

Pirveli M., 2009, Neolithic town - etiology and definition, International Conference: „The Contemporary Oriental City from a Linguistic, Literary and Cultural Perspective", Department of Interdisciplinary Eurasiatic Research of the Institute of Oriental Philology, Jagiellonian University, 20-22.V.2009, Kraków.

Słownik języka polskiego (red. W. Doroszewski), http://sjp.pwn.pl/doroszewski/przednio-azjatycki;5483199.html (dostęp: 20.02.2017).

Śremian G.E., 1953, Razwitie gorodow i gorodskoi żyzni w drewnej Armenii, Erewan.

Tsereteli G.V., 1942, Armazis bilingva. A Bilingual Inscription from Armazi near Mcheta in Gorgia (tekst w jęz. gruzińskim i angielskim), Tbilisi.

Vachuszti, 1941, Opis królestwa Gruzji, Tbilisi.

Willetts R.F.,1990, Miasto grecko-rzymskie, [w:] Cotterell A. (red.), Cywilizacje starożytne, Wydawnictwo Łódzkie, Łódź.

\section{GEORGIAN TOWN - THE SEMANTICS OF THE SELECTED TERMS}

Abstract Towns located on the area of modern Georgia has mostly ancient or early medieval origins. From the same period are coming much of the terms describing the urban, the town and its inhabitants. Aim of this article is to introduce urbanity in the context of the semantics of a few basic concepts. Since semantics and knowledge of the genesis of the term reveals the cultural capacity of the places to define which these terms are used. In the final part of the text discussed terms are seen as carriers of historical and cultural memory.

Keywords Semantics, cultural memory, Georgian town, borough, district, indigenous.

Dr Marika Pirveli Katedra Geografii Społecznej i Organizacji Przestrzeni

Wydział Nauk o Ziemi Uniwersytet Szczeciński e-mail: mariam.pirveli@usz.edu.pl 